\title{
Students Critical Thinking Reviewed from Field-Dependent and Field-Independent on Number Pattern Material
}

\author{
Nur Hijjah Arigawati', Kusnandi ${ }^{2}$ \\ 1,2Mathematics Education, Universitas Pendidikan Indonesia, Indonesia \\ 1arigawatinurhijjah@upi.edu, 2kusnandiabadi@yahoo.co.id
}

\begin{abstract}
Article History:

Received : 20-01-2021

Revised : 01-04-2021

Accepted : 01-04-2021

Online : 17-04-2021

\section{Keywords:}

Critical Thinking; Field-Independent and Field-Dependent;

Number Pattern;

One of the competencies or learning goals in the 2013 curriculum is to promote curiosity, creativity, and the ability to arranging problem to build critical thinking which are necessary for intelligent life. However, in reality, students's critical thinking skills in mathematics are still not satisfactory. Mathematic' material and critical thinking skills are two things that cannot be separated because mathematics material can be understood through critical thinking which is trained through learning mathematics. Learning number patterns aims to equip students to think critically, analyze, creatively, logically, and systematically. Students' critical thinking skills have related to the existence of cognitive aspects like how to complete a task, make procedures design, and be able to give the right solution in solving problems. This study aims to understand how students of junior high school solve math problems with number pattern material reviewed from students's critical thinking with Field-Dependent (FD) and Field-Independent (FI) cognitive style. The method used in this research is qualitative descriptive method with case study design. From the results of study conducted on 14 students, there were $64 \%$ students in the Independent field category and $36 \%$ students in the Dependent field category. Of the 2 students, among them taken in the Independent field category, they have high-level critical thinking skills and medium-level critical thinking skills. There are 2 students among those taken in the Dependent field category have critical thinking skills on medium level and low level.
\end{abstract}

\section{A. INTRODUCTION}

Reinforcing character education must can make students character grow in schools then students be able to think critically, collaboratively, creatively, and to communicate. So they are able to compete in the 21st century (Nurasiah et al., 2020). These competencies is needed for students in the 21st century and it called 4C that is creativity, critical thinking and problem solving, communication skills, and collaboration (Kembara et al., 2019).

Mathematics learning aims to set up students to finish daily problems, involves student in several steps. These steps consist of identifying the problem, thinking about the goal, brainstorming probable solutions, thinking through possible results, trying one of the solutions, and finally, evaluating the outcome (Ennis, 2011). By using mathematical operations or procedures, students must can read the problems, conduct symbolization, manipulate, and solve the problems (Seifi et al., 2012). Therefore, learning of mathematics is not only to aim the 
learning goals but also able to develop and evaluate argument to solve the problems. One of skills that must be expanded to reach these goals is the skill to think critically. In another words, critical thinking is really important for workplace, classroom, and for daily life (Ornstein et al., 2011).

In this study, researchers used 3 indicators of critical thinking skills, namely basic clarification, the bases for a decision, and inference. The use of these 3 indicators is in accordance with the critical thinking skills of junior high school students and in accordance with the definition of critical thinking skills used in this study.

Critical thinking as a form of thinking ability must be owned by everyone, including students because someone who thinks critically is able to find out the problems and formulate them clearly and precisely so that they can find a solution (Kurniati et al., 2018)(Changwong et al., 2018). This is what makes critical thinking skills very necessary for every student to be able to face problems, especially mathematic problems. Critical thinking as the ability to analyze, interpret, and process ideas and arguments (Fisher, 2011), besides that there is a relationship between mathematics and critical thinking, mathematical skills as well as problem solving, questioning, critical thinking, and analysis, are essential part of mathematics education (Su et al., 2016)(Tiruneh et al., 2014)(Widana, 2018).

The test results on mathematics in 16 junior high schools in several provinces in Indonesia are still very low, especially in mathematics applications. Application ability is a part of cognitive under the ability of analysis, synthesis, and evaluation (Marwan, Ikhsan, M, 2016). The low learning outcomes of mathematics are determined by many things, one of the things that affects is the students' critical thinking skills (Mulyanto et al., 2018). The habit of practicing critical thinking skills has not been fully applied to students in schools. As in the research conducted by Susanti, that is, students cannot find the main information on questions about number patterns, this is because students are not careful and don't understand the questions. Students are confused when they encounter different questions with practice questions (Eka \& Rini, 2019). This shows the students have low critical thinking skills, because according to Krulik and Rudnick that reasoning consists of basic thinking, critical thinking, and creative thinking (Firdaus et al., 2015). Thus, to improve student learning outcomes, critical thinking skills in mathematics learning must be developed immediately.

Students's critical thinking skills are closely related to the existence of cognitive aspects, that is how to complete a task, explain information in problem solving, design procedures, and be able to provide appropriate solutions in solving problems. Gurol said that reflective (reflective thinking) is very important for student and teacher (Gurol, 2011). Cognitive style can show a person's characteristics in responding, processing, memorizing, thinking, and using the information to respond an assignment is the cognitive style of Field Dependent (FD) and Field Independent (FI) (Maulidia et al., 2020).

Based on the problems above, this article will discuss about how students think critically in solving math's problems with number patterns, between students with Field Independent (FI) and Field Dependent (FD) use cognitive style in junior high schools. Thus, the researcher is interesting to report this research, with the title "Students Critical Thinking Reviewed from Field-Dependent and Field-Independent on Number Pattern Material". 
The purpose of this study is to understand hoe junior high school students solve math problem with algebraic material in terms of students' critical thinking with Field Dependent and Field Independent cognitive style in order to help students and teachers to identify and develop students' critical thinking skills, especially in solving math problems. And it can also help students and teachers in determining what learning strategies are appropriate for their cognitive style.

\section{B. METHODS}

This research used qualitative method with case study design. The subject in this study were students of grade VIII in Junior High School and The object in this study was Students's critical thinking skills reviewed from field-dependent and field-independent.

The steps taken in this study, starting from compiling the research design preparation and research instruments. The instrument in this study is Group Embedded Figures Test instrument, critical thinking skills test, and interview guidelines. The next step, giving the test use Group Embeded Figure Test (GEFT), analyzing the students's GEFT test results, from the GEFT test results then selecting students with field dependent and field independent cognitive style, give the critical thinking skills stage again to 2 field dependent students and 2 field students independent, interviewed 2 field dependent students and 2 independent field students, collected the results of GEFT written test data, the critical thinking skills stage test and the results of interviews, conducted data processing, described the results of data processing, and compiled research reports.

\section{RESULT AND DISCUSSION}

On the GEFT consists of three parts that is Part I consists 7 questions. while part II each consist of 9 questions. Every right answer will get 1 score and the wrong answer will get 0 score (Khatib \& Hosseinpur, 2011). Group Embeded Figure Test (GEFT) held on July 26, 2020, this test was attended by several students for grade VIII in SMPIT Fithrah Insani 2 and SMP Mutiara Bunda. The number of students who took the test was 14 students. The Student's result of GEFT test can be seen in the chart below:

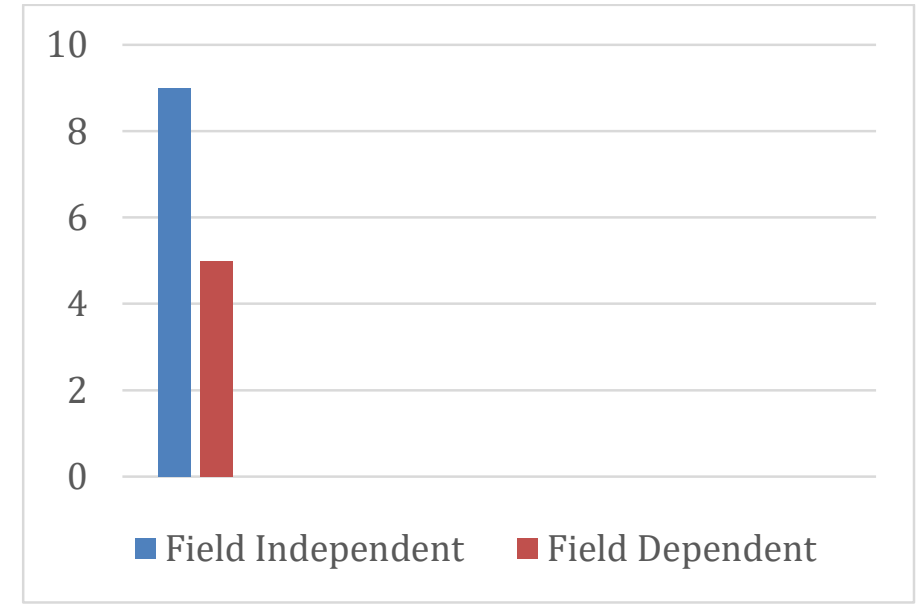

Figure 1. The result of GEFT test

In this study, 14 students of Grade VIII SMP divided into two groups based on the GEFT test that is 5 students with the FD cognitive style and 9 students with the FI cognitive style. The next sample selection is to take 2 students each from the FI cognitive style and FD cognitive style 
groups. The 5 students who had a cognitive style of FD, the researcher took as many as 2 students and from 9 students who had a cognitive style of FI, the researcher took 2 students to be sampled in this study. The four students sampled in this study are FI1 and FI2, they are students in the field independent (FI) category, FD1 and FD2 are students in the field dependent (FD) category. The critical thinking ability test was held on 11 September 2020 for SMPIT Fithrah Insani 2 students and 15 September 2020 for Mutiara Bunda Junior High School students. The critical thinking ability test is a test given to 4 students who have been selected as research subjects. In determining the research sample to do a critical thinking ability test was randomly selected. The purpose of this Ability test is as material in understanding students about critical thinking skills, especially in number pattern material. The test of critical thinking skills by 4 students who selected from the FI cognitive style and the FD cognitive style. The test is carried out online via Whatsapp and Zoom application. Students take a test containing 4 description questions.

The ability of students's critical thinking in problem solving math on number pattern material for grade VIII at SMPIT Fithrah Insani 2 and SMP Mutiara Bunda is done by grouping students into 3 levels, That is high, medium and low critical thinking skills. On Facione's theory, the ability to think critically of students with high critical thinking skills if students are able to fulfilled all the indicators of critical thinking, namely: 1) Offer explanations, 2) Build basic skills, and 3) conclude correctly that they must fulfilled. Furthermore, it is said that students who have moderate critical thinking abilities if students are able to fulfilled at least 2 indicators of critical thinking must be fulfilled. And finally, students who have low critical thinking abilities if students are only able to fulfilled one indicator of critical thinking or even students don't fulfilled a single indicator of critical thinking (Facione, 2011).

Table 1. The indicators of critical thinking skill category.

\begin{tabular}{ll}
\hline \multicolumn{1}{c}{ Category } & \multicolumn{1}{c}{ Explanation } \\
\hline High Critical Thinking Skill & Fulfilled 3 Indicators of Critical Thinking Skill \\
\hline Medium Critical Thinking Skill & Fulfilled 2 Indicators of Critical Thinking Skill \\
\hline Low Critical Thinking Skill & Fulfilled 1 or none indicator of critical thinking skill \\
\hline
\end{tabular}

Table 2. The result of critical thinking skill

\begin{tabular}{ccccc}
\hline & Indicator 1 & \multicolumn{2}{c}{ Indicator 2 } & Indicator 3 \\
\hline $\begin{array}{c}\text { Question } \\
\text { Code }\end{array}$ & No.1 & No.2 & No.3 & No.4 \\
\hline FI1 & $\sqrt{ }$ & $\sqrt{ }$ & $\sqrt{ }$ & $\sqrt{ }$ \\
\hline FI2 & & $\sqrt{ }$ & $\sqrt{ }$ & $\sqrt{ }$ \\
\hline FD1 & $\sqrt{ }$ & $\sqrt{ }$ & $\sqrt{ }$ \\
\hline FD2 & & & $\sqrt{ }$ & \\
\hline
\end{tabular}

Based on the results of critical thinking skills test with FI and FD cognitive style, it has known that students' critical thinking skills on number pattern material is differ. The discussion to describe a regarding critical thinking skills of students with Field Independent (FI) and Field dependent (FD) cognitive style on number pattern material at SMPIT Fithrah Insani 2 and SMP Mutiara Bunda are below : 
a. Subject FI1 with cognitive style in field Independent (FI)

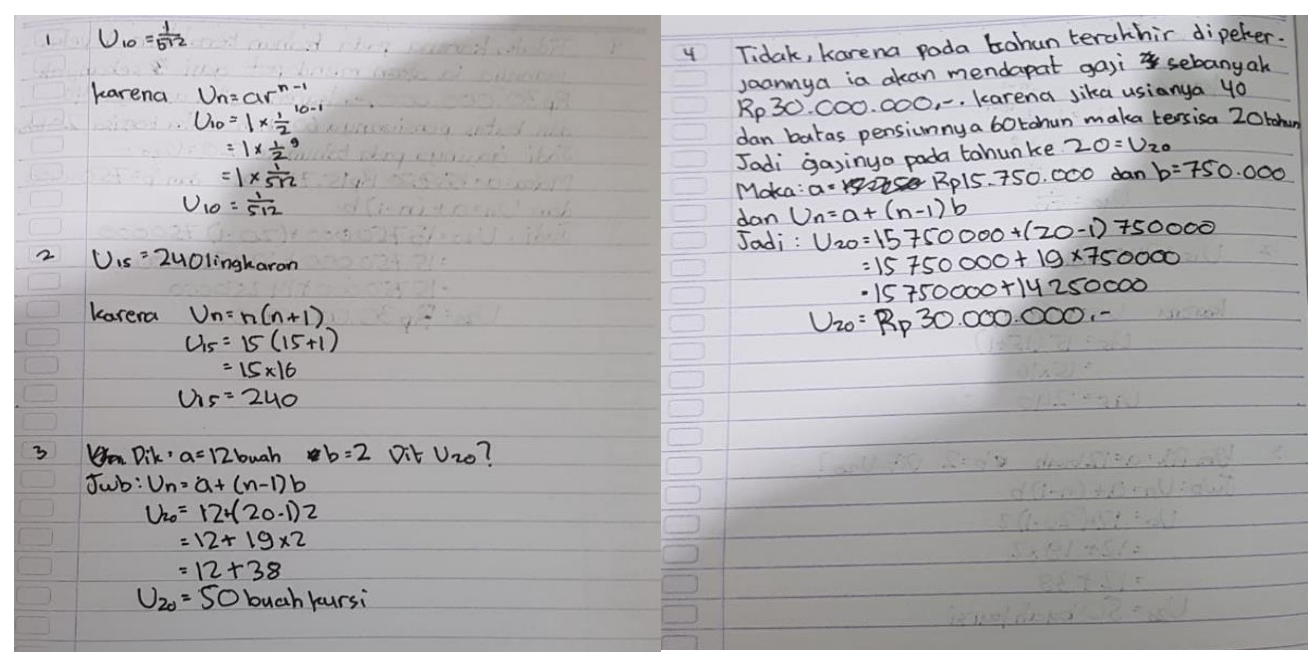

Figure 2. The result of critical thiking skill subject FI1

The student answer sheet shows that the FI1 thinking stage, students who have the Field Independent learning style when do the critical thinking skills test, is able to answer question No. 1, which is this is indicates of indicator provides a simple explanation, which means that students can answer by presenting the information in the problem related with the focus of the question, even though FI1 doesn't explain more on the answer sheet about the information contained in the questions, FI1 doesn't explanation of what is known in the questions, but can explain the information contained in the questions during the interview. FI1 is able to answer question No. 2 and No. 3, which has an indicator of building basic skills, it means students are able to design problem-solving procedures using rectangular number pattern formulas and arithmetic number patterns. FI1 could answers, but doesn't explain the formation of these number patterns on the answer sheet. FI1 could answer the question No. 4 which indicates FI1 could be right solution to answer the question No. 4. Beside that, FI1 doesn't use the number pattern formula very well. However, based on the interview, FI1 could explain the answer more clearly, but it didn't write down the answer sheet. FI1 understood all the intentions of the questions and realized that the formula used was wrong. FI1 could fulfilled the criteria in solving the questions by answering 4 of the 4 questions that has given correctly. FI1 is able to fulfilled 3 indicators of critical thinking skills, that is, being able to provide simple explanations, being able to build basic skills and being able to conclude correctly. Critical thinking skills of students who have high critical thinking abilities if students are able to fulfilled all 3 indicators of critical thinking and that is being able to offer simple explanations, being able to construct basic skills and being able to conclude must be fulfilled. Research shows that FI1 is able to fulfilled 3 indicators of critical thinking skills so that FI1 is classified as a student with high critical thinking skill. 
b. Subject F12 with cognitive style in Field Independent (F1)

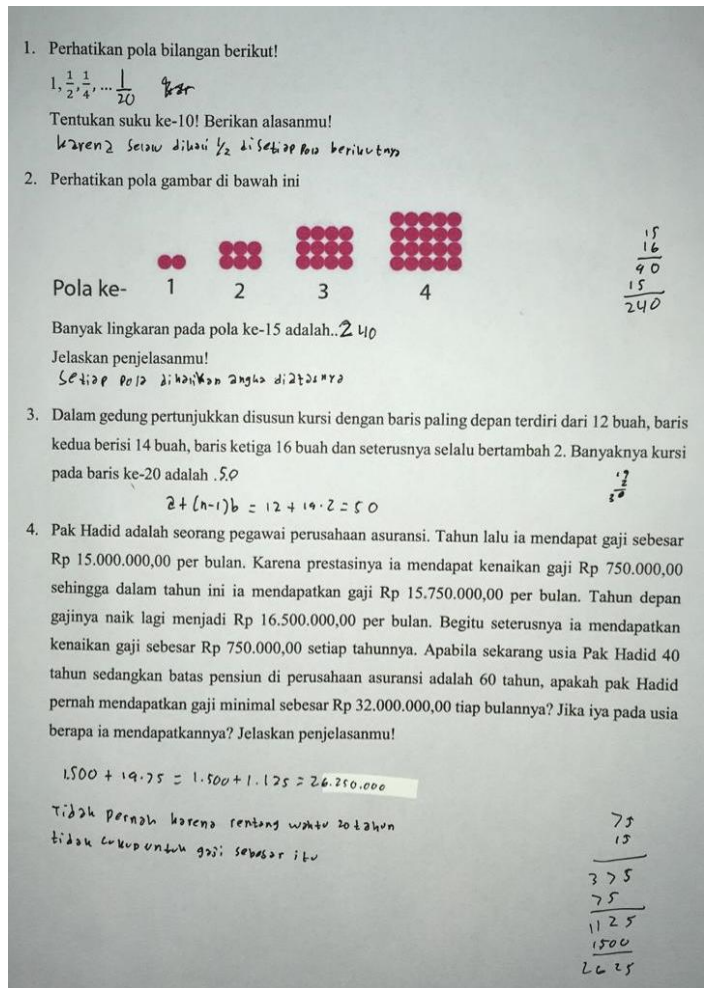

Figure 3. The result of critical thinking skill Subject FI2

Based on the results of the data, the FI2 thinking stage, students who have the Field Independent learning style in do critical thinking ability test, FI2 is only able to answer 3 questions correctly out of the 4 questions has given. FI2 wasn't correct in answering question No.1 and couldn't explain the information in the problem, it wasn't accordance with the focus of the question. Therefore FI2 didn't accomplish the first indicator to provide a offer explanation. FI2 is able to answer question No. 2 and No. 3, which has an indicator of building basic skills. It means students are able to design problem-solving procedures using the rectangular number pattern formula in No. 2 and arithmetic number patterns in No. 3, FI2 is able to provide answers and explanations during the interview, but doesn't explain the formation of the number pattern on the answer sheet. FI2 is able to provide an answer to question No. 4 which indicates that FI4 is able to provide the right solution to answer question No. 4. Based on the interview fragment, FI2 can also explain the answer more clearly, but it doesn't write down the answer sheet. FI2 understands all the meaning of the question. So it could be FI2 is able to fulfilled 2 indicators of critical thinking skills that is being able to build basic skills and being able to conclude with accuracy. The ability to think critically of students who have moderate critical thinking skills if students are able to fulfilled at least 2 indicators of critical thinking skills. So FI2 is classified as a student with medium critical thinking skill. 
c. Subject FD1 with cognitive style in Field Dependent (FD)

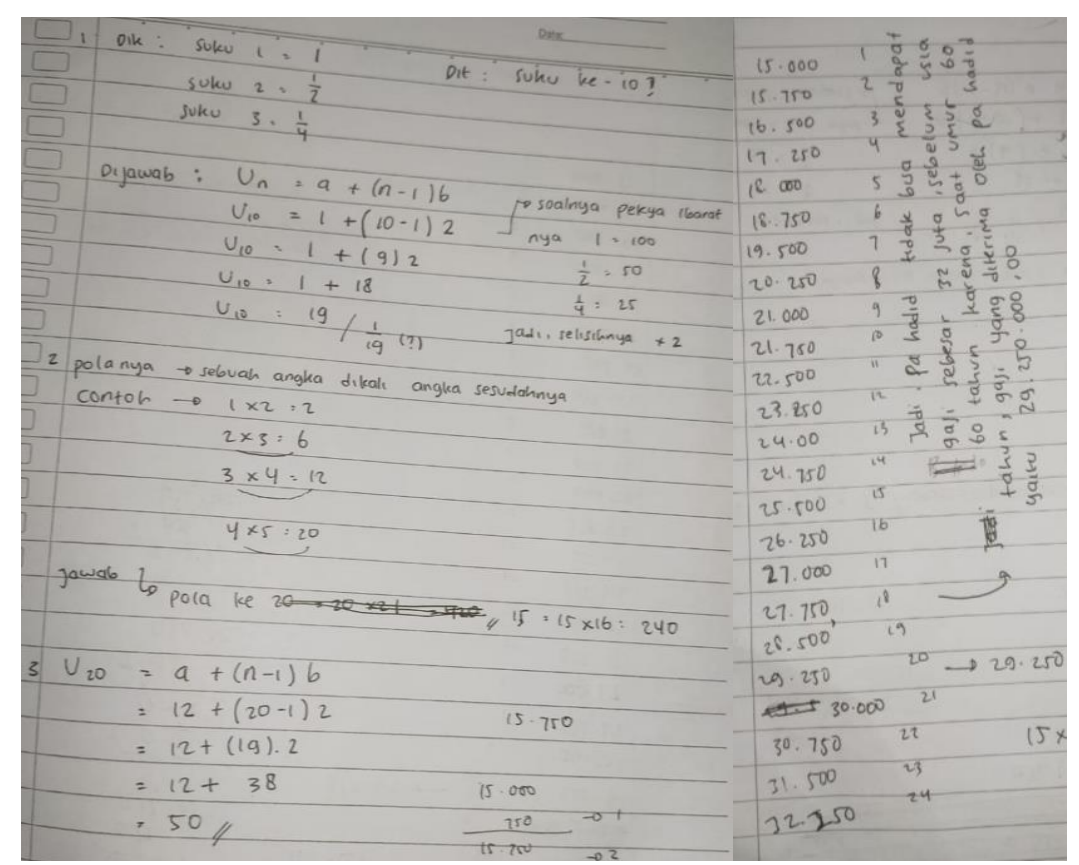

Figure 4. The Result of critical thinking skill subject FD1

Based on the results of the data, the FD1 thinking stage, that is student with a Dependent Field learning style do the critical thinking skills test has given, FD1 is only able to answer 3 questions correctly out of the 4 questions that has given. FD1 wasn't correct in answering question No.1 and couldn't explain the information in the problem according to the focus of the question, therefore FD1 didn't accomplish the first indicator, which to offer explanation. FD1 is able to answer question No. 2 and No. 3, which has an indicator of building basic skills, which means that students are able to design problem-solving procedures using the rectangular number pattern formula in No. 2 and arithmetic number patterns in No. 3, FD1 was able to provide answers and explanations during the interview, but didn't explain more fully on the answer sheet. FD1 is able to provide answers to question No. 4 which indicates that FD1 is able to supply a solution to answer question No. 4. Based on the interview, FD1 can explain the answer more clearly, it's just not accurate in the calculations, but FD1 understands all the meaning of the questions and can conclude the answer correctly. So it can be said that FD1 is able to fulfilled 2 indicators of critical thinking skills that is being able to build basic skills and being able to conclude with accuracy. The ability to think critically of students who have moderate critical thinking skills if students are able to fulfilled at least 2 indicators of critical thinking skills. FD1 shows that it is able to fulfilled 2 indicators, so it can be classified as FD1 with moderate critical thinking skill. 
d. Subject FD2 with cognitive style in Field Dependent (FD)

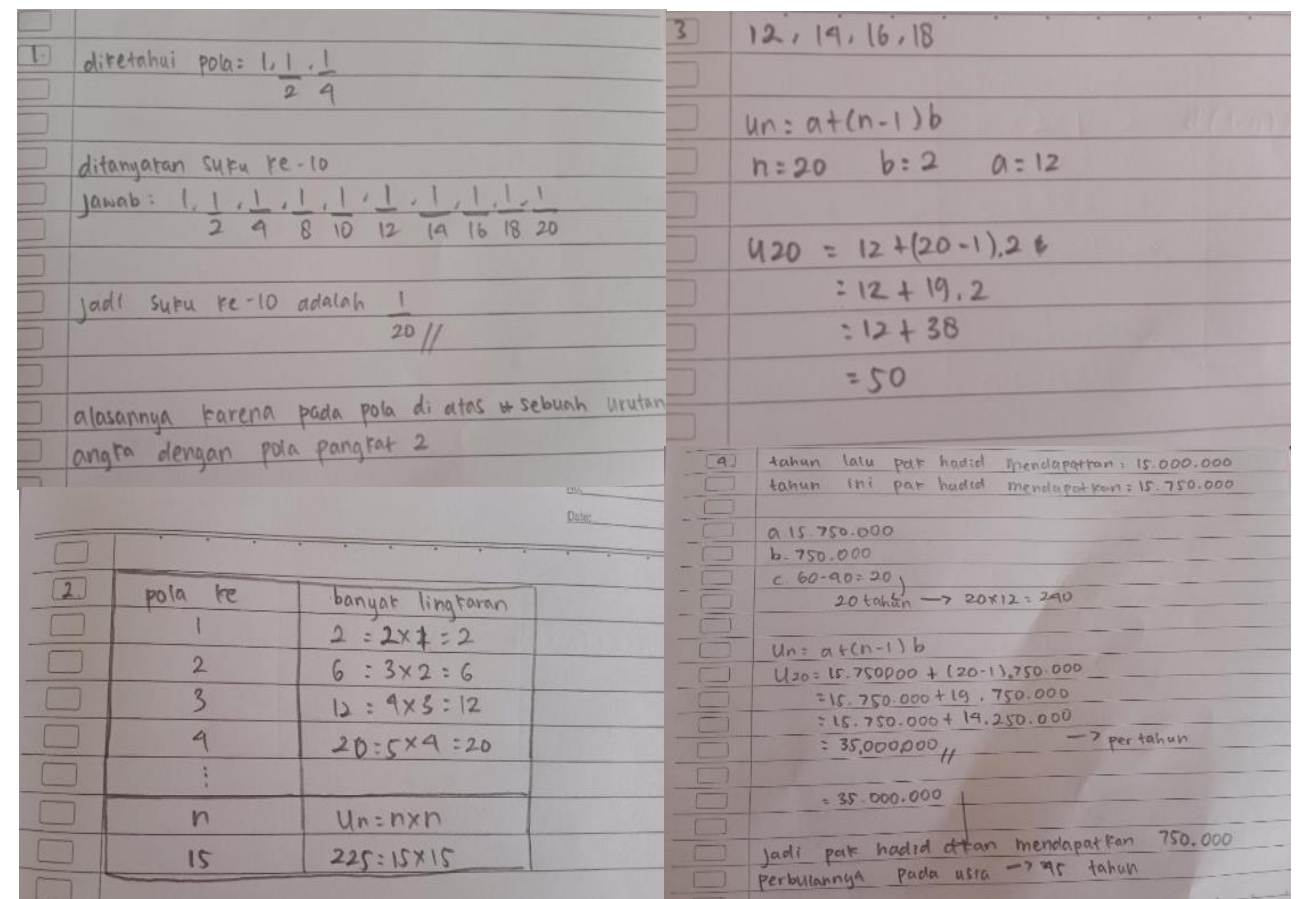

Figure 5. The Result of critical thinking skill subject FD2

Based on the results of the data, the FD2 thinking stage is student who have a Field Dependent learning style in do critical thinking skill test. FD2 shows that it is able to answer 1 of the 4 questions that is question No. 3. FD2 is able to fulfilled the indicators of building basic skills, which means that students are able to design problem-solving procedures using the arithmetic number pattern formula in No. 3. FD2 is unable to fulfilled the indicators providing simple explanations and concluding appropriately. The critical thinking ability of students who have low critical thinking skills if the student is only able to fulfilled one of the three indicators of critical thinking or even the student does not fulfilled any of the indicators of critical thinking. Based on the results of interviews with FD2 student only fulfilling the indicators of building basic skills, student have not been able to explain the information in the questions and have not been able to provide the conclusions contained in the questions, therefore FD2 students are classified as having low critical thinking skills.

Based on research at SMPIT Fithrah Insani 2 and SMP Mutiara Bunda, from the cognitive style data obtained, it appears that grade VIII students generally have a Field Independent (FI) cognitive style. FI cognitive style is a characteristic of individuals who tend to perceive objects as consisting of discrete parts and separate from their environment and be able to analyze in separating elements from their context with more analytical manner (Kamid et al., 2020). This means that FI students prefer to study independently. However, apart from students who are dominated by the Field Independent cognitive style, there are some students who fall into the Field Dependent category. FD cognitive style is a characteristic of individuals who tend to organize and process information globally so that their perceptions are easily affected by environmental changes (Kamid et al., 2020). This means FD students prefer to study in groups. 


\section{CONCLUSION AND SUGGESTIONS}

The ability to perform critical thinking reviewed on Field Independent at SMPIT Fithrah Insani 2 and SMP Mutiara Bunda, from the results study that has been conducted on 14 students of class VIII, the results obtained are $64 \%$ of students who belong to the Field Independent category. The 2 subjects, they were taken, that is the FI1 subject and the FI2 subject for the critical thinking skill test, which were categorized as having high critical thinking skills in FI1 subjects and moderate critical thinking skills on FI2 subjects. The ability to think critically reviewed on Field Dependent at SMPIT Fithrah Insani 2 and SMP Mutiara Bunda, the result are $36 \%$ of students fall into the Dependent Field category. 2 students among them who were taken for the critical thinking skill test, it was known that each subject had different levels of critical thinking skills. The critical thinking skills possessed by each subject are as follows: Subject FD1 in the Dependent Field category with moderate critical thinking skills. FD2 subject is in the Dependent Field category with low critical thinking skill. The result of this research can be used for a material information in order to develop research about Student critical thinking in problem solving with different characteristic.

\section{ACKNOWLEDGEMENT}

The authors would like to say thank you to UPI for academic support, students and teachers who give participation in this research.

\section{REFERENCES}

Changwong, K., Sukkamart, A., \& Sisan, B. (2018). Critical thinking skill development: Analysis of a new learning management model for Thai high schools. Journal of International Studies, 11(2), 37-48. https://doi.org/10.14254/2071-8330.2018/11-2/3

Eka, S., \& Rini, S. (2019). Analisis Kesalahan Siswa Dalam Menyelesaikan Soal Pola Bilangan Model Timms. MATHEdunesa, 8(2), 302-310.

Ennis, R. H. (2011). Critical Thinking: Reflection and Perspective Part I. In Inquiry: Critical Thinking Across the Disciplines (Vol. 26, Issue 1, pp. 4-18). https://doi.org/10.22329/il.v6i2.2729

Facione, P. a. (2011). Critical Thinking : What It Is and Why It Counts. Insight Assessment, ISBN 13: 9781-891557-07-1., 1-28. https://www.insightassessment.com/CT-Resources/Teaching-For-andAbout-Critical-Thinking/Critical-Thinking-What-It-Is-and-Why-It-Counts/Critical-ThinkingWhat-It-Is-and-Why-It-Counts-PDF

Firdaus, F., Kailani, I., Bakar, M. N. Bin, \& Bakry, B. (2015). Developing Critical Thinking Skills of Students in Mathematics Learning. Journal of Education and Learning (EduLearn), 9(3), 226. https://doi.org/10.11591/edulearn.v9i3.1830

Fisher, A. (2011). Critical Thinking An Introduction Second edition. In Cambridge University Press.

Gurol, A. (2011). Determining the reflective thinking skills of pre-service teachers in learning and teaching process. Energy Education Science and Technology Part B: Social and Educational Studies, $3(3)$.

Kamid, Rusdi, M., Fitaloka, O., Basuki, F. R., \& Anwar, K. (2020). Mathematical communication skills based on cognitive styles and gender. International Journal of Evaluation and Research in Education, 9(4), 847-856. https://doi.org/10.11591/ijere.v9i4.20497

Kembara, M., Rozak, R. W., \& Hadian, V. A. (2019). Research-based Lectures to Improve Students' $4 C$ (Communication, Collaboration, Critical Thinking, and Creativity) Skills. August. https://doi.org/10.2991/icollite-18.2019.50

Khatib, M., \& Hosseinpur, R. M. (2011). On the Validity of the Group Embedded Figure Test (GEFT). Journal of Language Teaching and Research, 2(3), 640-648. https://doi.org/10.4304/jltr.2.3.640648

Kurniati, Kusumah, Y. S., Sabandar, J., \& Herman, T. (2018). Mathematical Critical Thinking Ability. Journal of Educational Experts, 1(2), 69-80. http://journal.kopertis- 
4.org/index.php/jee/article/view/10

Marwan, Ikhsan, M, M. (2016). Meningkatan Kemampuan Berfikir Kritis Matematis Siswa SMK Melalui Model Pembelajaran Berbasis Masalah. Jurnal Didaktik Matematika, 3(2), 9-18. https://doi.org/10.23969/symmetry.v4i2.2085

Maulidia, F., Saminan, S., \& Abidin, Z. (2020). The Implementation of Problem-Based Learning (PBL) Model to Improve Creativity and Self-Efficacy of Field Dependent and Field Independent Students. Malikussaleh Journal of Mathematics Learning (MJML), 3(1), 13. https://doi.org/10.29103/mjml.v3i1.2402

Mulyanto, H., Gunarhadi, G., \& Indriayu, M. (2018). The Effect of Problem Based Learning Model on Student Mathematics Learning Outcomes Viewed from Critical Thinking Skills. International Journal of Educational Research Review, 3(2), 37-45. https://doi.org/10.24331/ijere.408454

Nurasiah, L., Priatna, B. A., \& Priatna, N. (2020). The effect of differentiated instruction on student mathematical communication ability. Journal of Physics: Conference Series, 1469(1). https://doi.org/10.1088/1742-6596/1469/1/012160

Ornstein, A. C., Pajak, E., \& Ornstein, S. B. (2011). Curriculum: Foundation, principles and issues, 7th edition.

Seifi, M., Haghverdi, M., \& Azizmohamadi, F. (2012). Recognition of Students' Difficulties in Solving Mathematical Word Problems from the Viewpoint of Teachers. Journal of Basic and Applied Scientific Research, 2(3).

$\mathrm{Su}$, H. F. H., Ricci, F. A., \& Mnatsakanian, M. (2016). Mathematical teaching strategies: Pathways to critical thinking and metacognition. International Journal of Research in Education and Science, 2(1), 190200. https://doi.org/10.21890/ijres.57796

Tiruneh, D. T., Verburgh, A., \& Elen, J. (2014). Effectiveness of Critical Thinking Instruction in Higher Education: A Systematic Review of Intervention Studies. Higher Education Studies, 4(1). https://doi.org/10.5539/hes.v4n1p1

Widana, I. W. (2018). Higher Order Thinking Skills Assessment towards Critical Thinking on Mathematics Lesson. International Journal of Social Sciences and Humanities (IJSSH), 2(1), 24-32. https://doi.org/10.29332/ijssh.v2n1.74 